\title{
Curriculum and Methods of Teaching Architectural Technology in Nigerian Polytechnics: Challenges and Implications on Practice Performance of Graduates
}

\author{
Udochukwu Obiamaka Marcel-Okafor \\ Department of Architectural Technology, Federal Polytechnic Nekede, Imo State, Nigeria
}

\begin{abstract}
This paper discusses the curriculum content and methods of teaching in architectural technology programmes in Nigerian polytechnics, and how these play out in preparing the polytechnic graduate of the programme for the professional practice in Nigeria. Three polytechnics offering architectural technology programmes were purposively selected for the study. The research method involved descriptive and thematic analysis of the curriculum contents and methods of teaching used in the schools, as well as responses from the primary data obtained using structured interviews administered to the tutorial staff of the selected polytechnics, and the HND graduates from December 2013 to October 2015 working in architectural firms or freelancing. Secondary data used were obtained from academic curriculum for architectural technology programmes of the selected polytechnics, refereed journals, some reports available from reliable internet sources and books. Chi square was used to test the significance of the teaching methods and courses taught on the effective performance of the graduates in professional practice.

The findings of this study revealed that the core courses have prepared the graduates to the limited challenges of designing and drafting. The paper recommends that a reassessment of the value system is inevitable if the programme in Nigeria must remain relevant in the face of global trends in architectural technology and the emerging roles of the architectural technologist. The paper concludes that tackling the issues of funding for the programme in the polytechnics and increased productivity incentives for the architectural technologists will abate the major challenges of the programme.
\end{abstract}

\section{Introduction}

This paper grows out of a desire to observe if what is being taught and how it is being taught is sufficient to prepare the architectural technology graduate with the necessary cognitive and practical abilities for the present work demands of architectural practice in Nigeria.
This is particularly relevant to the country at a period when graduate unemployment rate is at $25 \%$ [1]. The United Nations demographic experts have estimated that by 2050 over $70 \%$ of the population in

Nigeria would reside in the urban centres [2]. Nigeria, with a population of over 150 million people, $70 \%$ of who are classified as being poor and, an estimated annual growth rate of $3.2 \%$, remains the fastest urbanising and most populous country in SubSaharan Africa.

Architectural technology programmes suffer the same prejudice meted out on the entire polytechnic education in Nigeria which is worrisome; this is because of the general preference in Nigeria to paper certification which the university education favourably offers against the technical certification which the polytechnic education offers. This sociopolitical bigotry against technical education has devalued the entire polytechnic education despite the practice-based learning style inherent in it, which is germane to unleashing the technological potentials and breakthroughs needed for national development in the country.

Over 4000 architects have been registered and are statutorily permitted to practice in Nigeria [3]. The housing sector in Nigeria, where the services of these registered architects and by extension the architectural technologists are in high demand, is predominantly a problem-laden situation presented in qualitative and quantitative forms [4]. The United Nations study declares the cumulative housing shortage at 17 million units and, the ratio of registered architects to Nigerians reveal the dearth of qualified architectural manpower.

This consequently mounts daunting pressures on the available ones to handle the housing demands of the present and predicted urban population explosion and the attendant needs emanating thereof in the building industry in Nigeria. This is invariably of concern to researchers in the field more so in the area of how the architectural technologists are trained, what quality of training are available and how the training acquired facilitates the practice performance of the trained professionals.

The mission of the polytechnic education in Nigeria is teaching, research and public service for 
the production of quality graduates, innovative information and improvement in technology and the educational objectives are conceived in the effort by individual institutions to produce proficient higher and lower technicians that will occupy the middle level manpower cadre [5]. Architectural technology programmes offered in Nigerian polytechnics are accredited by the National Board for Technical Education (NBTE), leading to the award of National Diploma (ND) and Higher National Diploma (HND) certificates in Architectural technology. The mission of the programme is the provision of functional, technical, vocational and entrepreneurial education and training which targets individual and national development. The main objective of the programme is to provide contemporary and sustainable manpower nurtured by ICT-driven human resources development which will remain responsive to the dynamism of the practice environment in Nigeria.

Today, albeit more than half a century has passed since the establishment of the pioneer school of architecture in Nigeria, the challenges facing the programme are not only shrinking the capabilities of both the teachers and students, they also undermine the competitiveness of their graduates in the global market.

\section{Objectives}

The following objectives were considered:

i. To ascertain if the curriculum in use was relevant to the dynamic demands of architectural practice in Nigeria.

ii. If the methods of teaching are responsive to technological advances with the sole aim of producing proficient graduates who can effectively respond to the work demands in practice.

iii. How the training acquired facilitates the practice performance of the graduates.

This was with the intent to establish the core challenges that have affected the programme and contributed to the present dissatisfaction in the system.

\section{Literature Review}

\subsection{Curriculum}

The curriculum of architectural technology programme like other academic curricula of professions is the body of knowledge that houses all the experiences, skills, creativity and activities going on in the school environment in order to achieve educational goals [6]. The current curriculum content in the Nigerian schools of architecture is structured to have tutorial courses revolve around studio design which is the core course that carries both the highest contact hours and credit loads [7]. This is also the scenario in the architectural technology departments in polytechnics, where the design studio is both the teaching and learning environment as well as the core course of study of architecture students. This implies that it is germane to the study of architectural technology and as such dependent on the pedagogy and curriculum of the school [8].

[9] asserts that since the central issue in architecture is the quality of the human habitat, the goal of architectural education is generally directed towards the attainment of a humane and responsive environment. The extent to which this goal is successfully attained depends on the curriculum content as approved by the regulatory body and various polytechnics, and methods of teaching the courses adopted by the lecturers and technologists. [10] succinctly posits that the structure of the architectural curriculum should aim at giving expressions to and utilizing the factors of socioeconomic and technological transformations in Nigeria.

The curriculum of the ND and HND Architectural Technology programmes consists of four components;

1. General Studies: These include courses in art and humanities, mathematics and sciences, social and entrepreneurship studies. This component accounts for a maximum of $10 \%$ of the total contact hours for the programme.

2. Foundation Courses: These include courses in pure sciences, economics, statistics and account for 10 $15 \%$ of the total contact hours for the programme.

3. Professional Courses: These include theoretical and practical courses in the field of study and provide the student with cognitive and practical skills needed to practice. Consequently, they account for $70-80 \%$ of the contact hours for the programme.

4. SIWES for ND programme: the following criteria are used for assessment of this component; i) punctuality ii) attendance iii) general attitude to work iv) technical competence v) respect for authority vi) interest in the field [11].

The professional courses which make up the core courses are grouped into six main areas of study or instruction modules as follows;

1. Architectural design courses

2. Architectural graphics courses

3. Architectural professional administration courses

4. Building construction courses

5. Computer courses

6. Entrepreneurial/ Environmental Courses

\subsection{Teaching methods}

Good teaching is tuition that results in useful acquisition of knowledge. Good quality teaching requires a good combination of subject knowledge, teaching methodology, psychology of learning and of learners as well as astute resourceful attitudinal orientation characteristic of the teacher [12]. The 
current teaching method in architectural technology programmes in Nigeria was believed to have developed in Europe and was rooted in two schools: the Ecole des Beaux Arts and the Bauhaus [13]. The former was based on studio-oriented design education while the latter ushered in the lecture format to studios and played a complimentary role as the information acquired from the lecture series were intended to intellectually equip the trainees in their studio exercises [7].

Pedagogy-based training enables teachers appreciate the role of learning theory in the plan and purpose of class activities and in the selection and use of instructional technologies [14]. The learning theories which represent hypothetical structures necessary for the assimilation and effective utilisation of acquired knowledge are crucial to both the application of the teaching methods and the implementation of the curriculum in architectural technology. This implies that the strategies used to impart knowledge and the curriculum must reflect in the output or practice performance of the architectural technologist.

The polytechnics have also adopted the lecturing style of teaching which basically involves passing information orally and remains the exclusive of those in the lecturing cadre while the practical aspects of illustrations and student physical participation are handled by the technologists. The methods of teaching commonly used are lecture methods, discussion methods, and the demonstration methods. The lecture formats commonly used are;

1. The participatory/inquiry method

2. The problem solving method

3. The creative/construction method

4. The case study method

\subsection{Job requirement and practice performance}

The emphasis of this study is on the HND graduate of architectural technology, also referred to as the architectural technologist, and plays the primary role of assisting the architect in rendering services ranging from the outset to the completion and eventual handing over of all building projects to the client. Architectural technologists are the production workers, converting design purpose into substantial information that can be conveyed to the construction team, thereby playing a vital underground role as detailers and dependable data providers crisscrossing design and production boundaries [15]. [16] posits that the indices for assessing the performance of architects and by extension architectural technologists in professional practice refer to those criteria used to measure the extent of services rendered based on review of literature on their responsibilities and further states that no one set of criteria totally explicates their performance. [17] defines performance basically as the measurement of what is accomplished in reality, against what is the expected work target.

The job requirement for the HND graduate entails;

1. Ability to undertake preliminary site investigation in relation to orientation, landscape among others.

2. Show understanding of basic architectural design principles and methods.

3. Assist in the design and preparation of spatial relationship, circulation and area diagrams.

4. Prepare space programmes and working drawings for architectural projects.

5. Detail simple building components in wood, plastic, metal and concrete.

6. Make presentation drawings of architectural works and draw detailed perspective with necessary rendering and requisite colour scheme.

7. Assist in the supervision of construction works and make progress reports on building projects.

8. Assist in the supervision of maintenance of building structures, assist with cost projections and targets for building projects. The graduates are expected to exhibit proficiency in the use of architectural software packages in the production of the architectural drawings.

9. Assist with cost projections and targets for building projects [11]

The study identified a set of criteria based on the requirements and job expectations of the architectural technologists by their superiors in the architectural firms surveyed and the following made up the bulk of work expectations;

1. Ability to make sketches based on the brief.

2. Ability to effectively incorporate ideas and comments from superiors in the design stages.

3. Effectively produce presentation, perspective and detailed drawings using appropriate software.

4. Ability to produce designs that satisfy the demands in the brief.

5. Ability to produce designs based on standards.

6. Ability to produce designs based on budget and cost estimates.

7. Complete designs within the target time frame.

8. Ability to assist in supervision of construction works.

9. Ability to relate cordially with other members of the construction team.

10. Ability to make progress reports.

\subsection{Challenges of Architectural Technology Programmes in Nigeria}

Studies have revealed that there are numerous factors that confront the programme in Nigeria, foremost being the attitude of the Nigerian society to the entire polytechnic education which has continued to devalue and relegate the programmes and products to a pitiable state of redundancy. [18] opined that the 
new entrants experienced gratuitous bottlenecks in the registration and entire course of the programme which range from problems of accommodation to schoolwork pressures and having to work under very inclement conditions chiefly caused by incessant and erratic power supply.

The over extended period of tutelage training being part of the process of preparing and writing the Professional Practice Examination (PPE), a prerequisite for the professional registration and certification to practice have also been listed as one of the challenges. [10] opined on the need for a new direction in architectural education in Nigeria, emphasizing that the fundamental mission of a new educational structure is to overthrow the vestiges of the Beaux-Arts model which outlives its relevance after providing the basic knowledge of architectural study. The need for an educational structure relevant to the concept of architecture as a cultural phenomenon particularly at the second and terminal level of study became necessary considering the dynamics of the Nigerian milieu.

[19] stated the challenge of unemployment after graduation and suggested revisiting the curriculum specifically to integrate self-employment strategies. [20] and [8] succinctly emphasised the need for an improvement in the architecture curriculum to address the challenges of housing inadequacies, squatter control and other environmental dilapidation issues as well as a review particularly in the design studio to inculcate further sustainability studies with the view to enhance environmentally-conscious design techniques. [21] rightly observed that the present arrangement has not provided the scope to enable the graduates efficiently discharge their functions and train further to become experts and specialists without unnecessary obstructions.

The current universal change of educational curricula in most fields of human endeavour have compelled stakeholders in the profession to clamour for a paradigm shift in architectural education programme which included a restructuring of the curriculum to effectively respond to the challenges of architectural practice in the third millenium [9], [22] and [23].

\section{Research Methodology}

The purposive sampling technique was used in the selection of three (3) government owned polytechnics that offer Architectural Technology programme in Nigeria. The polytechnics are the Federal Polytechnic Nekede, Owerri, Abia State Polytechnic, Aba, and Ken Saro-Wiwa Polytechnic, Bori Rivers State. Primary data were obtained using structured interviews administered to the tutorial staff of the selected polytechnics, and the HND graduates from December 2013 to October 2015 working in architectural firms or freelancing. 150 graduates were selected out of the 240 HND graduates of the programme using the Taro Yamane sample size formula. 41 tutorial staff were surveyed from the 3 schools to ascertain the methods of teaching prevalent in the schools. The interviews focused on teaching methods used in all three polytechnics, assessment of performance of the graduates in practice on a five-point scale as well as challenges encountered. Secondary data used were obtained from academic curriculum for architectural technology programmes of the selected polytechnics, refereed journals, some reports available from reliable internet sources and books.

The data collected was analysed using methods of frequencies, percentages and Chi square to test the significance of the teaching methods and courses taught on effective performance of the graduates in their practice.

The intention of this study was to analyse courses presented in the curricula with regard to the job requirements and expectations of the graduates to ascertain their relevance to present day architectural practice. To effectively measure the practice performance of the graduates, the study examined the benchmark for ascertaining work expectations as stipulated in the NBTE regulated curriculum for architectural technology programme and the actual work requirements and achievements in the professional practice.

\section{Findings}

i.All the three departments of architectural technology are in government owned polytechnics and have been fully accredited at both the National Diploma (ND) and Higher National Diploma (HND) levels by the National Board for Technical Education (NBTE) (see Table 1).

Table 1. Showing background information of selected institutions

\begin{tabular}{|c|c|c|c|}
\hline $\begin{array}{l}\text { Name of } \\
\text { Institution }\end{array}$ & $\begin{array}{l}\text { Federal } \\
\text { Polytechnic } \\
\text { Nekede, } \\
\text { Owerri, Imo } \\
\text { State } \\
\end{array}$ & $\begin{array}{l}\text { Abia State } \\
\text { Polytechnic } \\
\text { Aba,Abia } \\
\text { State }\end{array}$ & $\begin{array}{l}\text { Ken Saro- } \\
\text { Wiwa } \\
\text { Polytechnic } \\
\text { Bori, Rivers } \\
\text { State } \\
\end{array}$ \\
\hline $\begin{array}{l}\text { Year of } \\
\text { establishment }\end{array}$ & 1978 & 2007 & 2002 \\
\hline $\begin{array}{l}\text { Ownership } \\
\text { Status }\end{array}$ & $\begin{array}{l}\text { Federal } \\
\text { government }\end{array}$ & $\begin{array}{l}\text { State } \\
\text { government }\end{array}$ & $\begin{array}{l}\text { State } \\
\text { government }\end{array}$ \\
\hline $\begin{array}{l}\text { Programmes } \\
\text { offered }\end{array}$ & ND/HND & ND/HND & ND/HND \\
\hline $\begin{array}{l}\text { Accreditation } \\
\text { Status }\end{array}$ & $\begin{array}{l}\text { Fully } \\
\text { accredited }\end{array}$ & $\begin{array}{l}\text { Fully } \\
\text { accredited }\end{array}$ & $\begin{array}{l}\text { Fully } \\
\text { accredited }\end{array}$ \\
\hline
\end{tabular}

ii. The NBTE minimum standard provides the uniform benchmark for the curriculum contents in the three schools, all three departments have fully integrated the entrepreneurial courses in line with Government policy, and slight variations exist with the inclusion of architectural appreciation and theory 
and environmental science in the first semester of the HND I and HND II programmes respectively at the Federal Polytechnic Nekede which were both aftermaths of a curriculum review exercise carried out internally in the school (see Table 2 and Table 3 ).

Table 2. Showing list of courses offered at HND1 programme

\begin{tabular}{|c|c|c|}
\hline $\begin{array}{l}\text { Federal Polytechnic } \\
\text { Nekede, Owerri, Imo } \\
\text { State }\end{array}$ & $\begin{array}{l}\text { Abia State } \\
\text { Polytechnic } \\
\text { Aba, Abia State }\end{array}$ & $\begin{array}{l}\text { Ken Saro-Wiwa } \\
\text { Polytechnic } \\
\text { Bori, Rivers } \\
\text { State }\end{array}$ \\
\hline $\begin{array}{l}1989 \text { reviewed version } \\
\text { of NBTE accredited } \\
\text { curriculum and course } \\
\text { specification }\end{array}$ & $\begin{array}{l}1989 \text { version of } \\
\text { NBTE accredited } \\
\text { curriculum and } \\
\text { course } \\
\text { specification }\end{array}$ & $\begin{array}{l}1989 \text { version of } \\
\text { NBTE accredited } \\
\text { curriculum and } \\
\text { course } \\
\text { specification }\end{array}$ \\
\hline ARC311 Architectural & ARC311 & ARC311 \\
\hline Design and Report & $\begin{array}{l}\text { Architectural } \\
\text { Design and } \\
\text { Report }\end{array}$ & $\begin{array}{l}\text { Architectural } \\
\text { Design and } \\
\text { Report }\end{array}$ \\
\hline $\begin{array}{l}\text { ARC312 Architectural } \\
\text { Delineation }\end{array}$ & $\begin{array}{l}\text { ARC312 } \\
\text { Architectural } \\
\text { Delineation }\end{array}$ & $\begin{array}{l}\text { ARC312 } \\
\text { Architectural } \\
\text { Delineation }\end{array}$ \\
\hline ARC313 Construction & ARC313 & ARC313 \\
\hline Methods & $\begin{array}{l}\text { Construction } \\
\text { Methods }\end{array}$ & $\begin{array}{l}\text { Construction } \\
\text { Methods }\end{array}$ \\
\hline $\begin{array}{l}\text { ARC314 Architectural } \\
\text { Detailing }\end{array}$ & $\begin{array}{l}\text { ARC314 } \\
\text { Architectural } \\
\text { Detailing }\end{array}$ & $\begin{array}{l}\text { ARC314 } \\
\text { Architectural } \\
\text { Detailing }\end{array}$ \\
\hline ARC 315 & ARC 315 & ARC 315 \\
\hline Technical Report & Technical Report & Technical Report \\
\hline Writing & Writing & Writing \\
\hline ARC316 & ARC316 & ARC316 \\
\hline Building Climatology & $\begin{array}{l}\text { Building } \\
\text { Climatology }\end{array}$ & $\begin{array}{l}\text { Building } \\
\text { Climatology }\end{array}$ \\
\hline $\begin{array}{l}\text { ARC } 317 \text { Site Planning } \\
\text { and Landscape Design }\end{array}$ & $\begin{array}{l}\text { ARC } 317 \text { Site } \\
\text { Planning and } \\
\text { Landscape } \\
\text { Design }\end{array}$ & $\begin{array}{l}\text { ARC } 317 \text { Site } \\
\text { Planning and } \\
\text { Landscape } \\
\text { Design }\end{array}$ \\
\hline $\begin{array}{l}\text { ARC } 318 \text { Estimating } \\
\text { and Tendering }\end{array}$ & $\begin{array}{l}\text { ARC } 318 \\
\text { Estimating and } \\
\text { Tendering }\end{array}$ & $\begin{array}{l}\text { ARC } 318 \\
\text { Estimating and } \\
\text { Tendering }\end{array}$ \\
\hline $\begin{array}{l}\text { Advanced Mathematics } \\
\text { for Architecture }\end{array}$ & $\begin{array}{l}\text { Advanced } \\
\text { Mathematics for } \\
\text { Architecture }\end{array}$ & $\begin{array}{l}\text { Advanced } \\
\text { Mathematics for } \\
\text { Architecture }\end{array}$ \\
\hline $\begin{array}{l}\text { Outline History of } \\
\text { Africa } \\
\text { Architectural } \\
\text { Appreciation/Theory }\end{array}$ & $\begin{array}{l}\text { Outline History } \\
\text { of Africa } \\
\text { N/A }\end{array}$ & $\begin{array}{l}\text { Outline History } \\
\text { of Africa } \\
\text { N/A }\end{array}$ \\
\hline
\end{tabular}

Table 3. Showing list of courses offered at HND11 programme

\begin{tabular}{lll}
\hline $\begin{array}{l}\text { Federal Polytechnic } \\
\text { Nekede, Owerri, } \\
\text { Imo State }\end{array}$ & $\begin{array}{l}\text { Abia State } \\
\text { Polytechnic } \\
\text { Aba,Abia State }\end{array}$ & $\begin{array}{l}\text { Ken Saro-Wiwa } \\
\text { Polytechnic Bori, } \\
\text { Rivers State }\end{array}$ \\
\hline $\begin{array}{l}\text { ARC411 } \\
\text { Architectural }\end{array}$ & ARC411 & ARC411 \\
Design and Report & Architectural & Architectural \\
III & & Design and Report and Report \\
ARC412 & ARC412 & ARC412 \\
Architectural & Architectural & Architectural \\
Delineation III & Delineation III & Delineation III \\
ARC413 & ARC413 & ARC413 \\
Construction & Construction & Construction \\
Drawings I & Drawings I & Drawings I \\
ARC414 Electrical & ARC414 Electrical & ARC414 Electrical \\
\hline
\end{tabular}

\begin{tabular}{lll}
\hline Building Services & Building Services & Building Services \\
ARC415 & ARC415 & ARC415 \\
Specification & Specification & Specification \\
Writing & Writing & Writing \\
ARC416 Principles & ARC416 & ARC416 \\
and Practice of & Principles and & Principles and \\
Building & Practice of & Practice of \\
Maintenance & Building & Building \\
& Maintenance & Maintenance \\
ARC 417 & ARC 417 & ARC 417 \\
Application of & Application of & Application of \\
Computer in & Computer in & Computer in \\
Architecture II & Architecture II & Architecture II \\
ARC 418 & N/A & N/A \\
Environmental & & \\
Science & & \\
Measurement of & Measurement of & Measurement of \\
Building Works II & Building Works II & Building Works II \\
Introduction & Introduction & Introduction \\
Psychology & Psychology & Psychology \\
Entrepreneurship & Entrepreneurship & Entrepreneurship \\
Development & Development & Development \\
\hline Source: Author, 2017 & & \\
& &
\end{tabular}

iii. The study revealed that $94(62.7 \%)$ respondents agreed that the knowledge they acquired in school assisted them in their new place of work, while 56 $(37.3 \%)$ strongly agreed. There were no responses for 'disagree', 'strongly disagree', and 'No Idea'.

iii. Lecturing is the predominant teaching method, the lecturers are freely disposed to any of the lecture format; creative/constructive method, problem solving method, inquiry method and case.

iv. The results showed that $18(43.9 \%)$ of the staff respondents from the schools are of the opinion that course content and class size determine their choice of teaching method adopted, while 15 (36.6\%) were of the opinion that course content only determines the choice and $8(19.5 \%)$ are influenced by class size alone (see Table 4).

Table 4. Showing factors that influence choice of teaching methods

\begin{tabular}{|l|c|c|c|c|}
\hline & Frequency & Percent & Valid Percent & Cumulative \% \\
\hline Course content & 15 & 36.6 & 36.6 & 36.6 \\
\hline Class size & 8 & 19.5 & 19.5 & 56.1 \\
\hline Course content and class size & 18 & 43.9 & 43.9 & 100.0 \\
\hline Total & 41 & 100.0 & 100.0 & \\
\hline
\end{tabular}

Source: Author, 2017

v. The study revealed that $26(63 \%)$ of the respondents ranked the performance of their students as average, while $15(36.6 \%)$ said their students performed above average. There were no responses for below average and poor performance (see Table 5). 
Table 5. Showing the responses on the performance of the students

\begin{tabular}{lrrrr}
\hline & Frequency & Percent & $\begin{array}{c}\text { Valid } \\
\text { Percent }\end{array}$ & $\begin{array}{c}\text { Cumulative } \\
\text { Percent }\end{array}$ \\
\hline Above & 15 & 36.6 & 36.6 & 36.6 \\
average & 26 & 63.4 & 63.4 & 100.0 \\
Average & & & & \\
Total & 41 & 100.0 & 100.0 & \\
& & & & \\
\hline
\end{tabular}

Source: Author, 2017

Table 6. Contingency Table showing the effectiveness of courses learnt and perceived impact in places of work

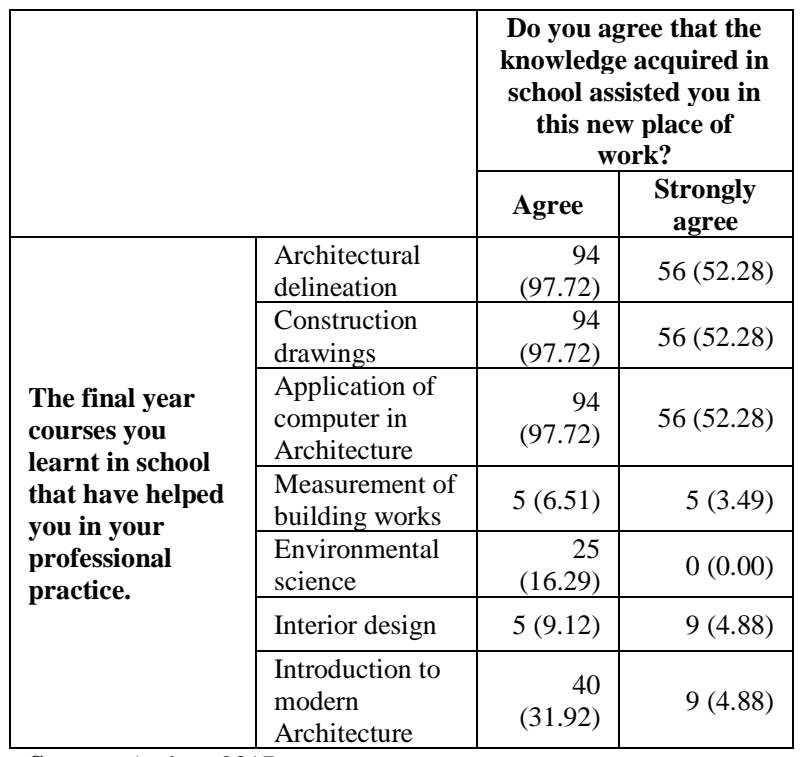

Source: Author, 2017

Table 7. Showing the Pearson Chi-Square Tests

\begin{tabular}{llr}
\hline & \multicolumn{1}{c}{$\begin{array}{c}\text { Do you agree that the } \\
\text { knowledge acquired in } \\
\text { school assisted you in this } \\
\text { new place of work? }\end{array}$} \\
& & 26.811 \\
The final year courses you & Chi- & 6 \\
learnt in school that have & square \\
helped you in your & df \\
professional practice. & P- & 0.00 \\
\hline Source: Author, 2017 & value &
\end{tabular}

Source: Author, 2017

\section{Discussions}

Contingency Table showing effectiveness of courses learnt and perceived impact in places of work. The p-value $(0.00)$ which is less than the alpha $(0.05)$ in the table above shows that there is a significant association between the final year courses taught and the graduated students' performance in their work places. This implies that the teaching methods were effective

The HND graduates assessed revealed high proficiency in design-oriented tasks and poor ranking on ability to work with site workers as well as poor report writing. This is due to the fact that the site workers were generally reluctant to receive instructions from them owing to age and experience. They were also generally expected to give their reports orally which explained the low ranking for written report.

Latent challenges that were generally referred to but which the scope of the study did not consider included; securing funds to develop outstanding design proposals, and the general economic downturn in the country that has hampered activities in the building construction industry

\section{Recommendations}

The following recommendations are proposed:

1. Adequate provisions of infrastructural facilities to effectively implement the shift from traditional method of teaching and learning to the modern method which will encourage assimilation of design and technological advances of the 21st century.

2. Collaboration of polytechnics in the regular periodic review and implementation of the curriculum so as to have a common curriculum especially for core courses where minor variations can be obtainable in the electives.

3. Courses on strategic policy-making and implementation should be introduced since the architectural technologists are responsible for practical skills and represent the work-horses of architectural practices. They should be taught how to strategically deliver services as well as assist in policy-making of housing delivery.

4. There needs to be a paradigm shift in the value system for polytechnic education in the country which will contribute intensely to socioeconomic development in Nigeria by way of placing the technical education in its right place and encourage more individuals to opt for the polytechnic education and receive job satisfaction through enhanced productivity. 
Table 8. Assessment of the HND graduates working in architectural firms

\begin{tabular}{|c|c|c|c|}
\hline Criteria for assessment & $\begin{array}{l}\text { Courses that target the } \\
\text { criterion }\end{array}$ & $\begin{array}{c}\text { Mean } \\
\text { assessment } \\
\text { rating }\end{array}$ & Rank \\
\hline Ability to make sketches based on the brief. & Architectural Delineation & 4.15 & very good \\
\hline $\begin{array}{l}\text { Ability to incorporate } \\
\text { superior comments }\end{array}$ & Architectural Design & 4.55 & excellent \\
\hline Ability to produce drawings using software. & $\begin{array}{l}\text { Construction Drawings } \\
\text { Architectural Delineation and } \\
\text { Application of Computer } \\
\text { In Architecture II }\end{array}$ & 4.65 & excellent \\
\hline Ability to produce designs that satisfy brief & Architectural Design & 3.80 & good \\
\hline Ability to produce standard designs. & $\begin{array}{l}\text { Architectural Design and } \\
\text { Professional Administration }\end{array}$ & 3.65 & good \\
\hline Ability to produce cost effective designs & $\begin{array}{l}\text { Architectural Design and } \\
\text { Estimating and Tendering }\end{array}$ & 3.95 & good \\
\hline Complete designs within the target time frame. & $\begin{array}{l}\text { Architectural Design and } \\
\text { Professional Admin. }\end{array}$ & 4.20 & very good \\
\hline $\begin{array}{l}\text { Ability to assist in supervision of construction } \\
\text { works. }\end{array}$ & $\begin{array}{l}\text { Construction Methods, } \\
\text { Principles and Practice of } \\
\text { Building Maintenance }\end{array}$ & 3.05 & $\begin{array}{l}\text { Fairly } \\
\text { good }\end{array}$ \\
\hline $\begin{array}{l}\text { Ability to work with other members of the } \\
\text { construction team. }\end{array}$ & $\begin{array}{l}\text { Introduction } \\
\text { Psychology }\end{array}$ & 2.60 & fair \\
\hline Ability to make progress reports. & Technical Report Writing & 1.50 & poor \\
\hline
\end{tabular}

\section{Conclusion}

This paper has documented the current curriculum contents of some polytechnics in Nigeria as well as the job expectations of the architectural technologists. Based on the literature it is critical that training the professionals that are involved in the housing delivery services must be inclusive, buoyant and in line with modern advances in design and technology in order to attain far-reaching results. The study has shown that improving the quality and methods of teaching as well as periodic review of the curriculum content are germane to quality of graduates and their professional performance. The results will include effective amelioration of the housing conditions in the country, increased patronage of technical education and overall national development and productivity.

\section{References}

[1] Trading Economics. Nigeria Unemployment Rate. Trading Economics, https://tradingeconomics.com (Access Date: 29 May, 2017).

[2] Worldometers. Elaboration of Data by the United Nations, Department of Economic and social affairs, population division. World Population Prospects the 2015 revision. [Online] 2015. [Cited: March 02, 2017.] http://www.worldometers.info (Access Date: 14 June, 2017). 
[3] Architects Registration Council of Nigeria. Register of Architects Entitled to Practice in the Federal Republic of Nigeria. Abuja: ARCON, 2016.

[4] Olayiwola, L. M., Adeleye, O. and Ogunshakin, L. Public Housing Delivery in Nigeria: Problems and Challenges. XXXIII IAHS world congress on housing. Transforming housing environments through design. Pretoria, South Africa: s.n., September 2005.

[5] Ob'lama, M S. The NBTE, NIA, ARCON and Architectural Education in Nigerian Polytechnic system: A call for more collaboration. 2006, AARCHES Journal, pp. 29-35.

[6] Asoegwu, A O. Curriculum and Instructional Strategies. 1, 2006, A journal of Nigerian Languages and Culture, Vol. 9.

[7] Agbo, N O, Ogbonna, A C and Okwoli, F P. A Reflection on the Conflicts and Reconciliations between Taught (Academic) and Practical Architectural Designs. October-December 2004, AARCHES Journal, Vol. 3, pp. 47-51.

[8] Olotuah, A O, Taiwo, A A and Ijatuyi, O O. Pedagogy in Architectural Design Studio and Sustainable Architecture in Nigeria. Rome - Italy: MCSER Publishing, May 2016, Journal of Educational and Social Research, Vol. 6, pp. 157-164. 2240-0524.

[9] Olotuah, A O. At the Crossroads of Architectural Education in Nigeria. 2, September 2006, CEBE Transactions, online journal of the centre for Education in the Built Environment, Vol. 3, pp. 80-88.

[10] Adeyemi, E A. Structure of Part in Education. AprilJune 1988, Nigerian Institute of Architects Journal N.I.A.J, pp. 34-36.

[11] National Board for Technical Education, NBTE. Curriculum and Course specification in Architectural Technology. 1994.

[12] Felder, R $\mathrm{M}$ and Brent, R. How to Improve Teaching Quality. 1999, Quality Management Journal, Vol. 6, pp. 9-21.

[13] Udeh, C A. Balancing the Practicabilities with Behavioural Analysis in Today's Architectural Education. 1990, AARCHES Journal, pp. 22-25.

[14] Okojie, M C, Olinzock, A A and Okojie-Boulder, T C. The Pedagogy of Technical Intergration. The Journal of Technology studies 2006. https//doi.org/10.21061/jot s.v32i2.a.1 (Access Date: 25 April, 2017).

[15] Emmitt, S. Architectural Technology. Oxford: Blackwell Science Ltd, 2002.

[16] Oyedele, L O and Tham, K W. Building and Environment. www.elsevier.com/locate/buildenv (Access Date: May 30, 2017).

[17] Rush, R D. The building system integration handbook. Buston: Butterworths-Heineman, 1986.
[18] Waziri, S G and Osunkunle, A. Travails of The Polytechnic Architectural Technologist in Nigeria. 2010, Journal of Research in Education and Society, Vol. 1, pp. 104-110.

[19] Okpoechi, C U Equipping the Polytechnic Graduate of Architecture for the Reality of Self-Employment. 2006, AARCHES Journal, pp. 7-17.

[20] Anunobi, A. Training of Architects to Meet the Challenges of the 21st Century: A case for a New Curriculum Approach. 2006, AARCHES Journal, Vol. 5, pp. 1-6.

[21] Nkwogu, U O. Architectural Education for Nigeri an Development. 2008, Architects Colloquium, pp. 65-85.

[22] Arayela, O. An Introspection into Forty years of Architectural Practice in Nigeria (1960-2000) - The way Forward for Architects and Architecture in Nigeria. 2001, AARCHES Journal.

[23] Sa'ad, H T.The Changing Role of the Architect and Architecture in the Context of the ever-changing Technological Socio-economic and political global Environments in Nigeria. 2001, Aarches Journal. 